\title{
The notion of sewage as waste: a study of infrastructure change and institutional inertia in Buenos Aires, Argentina and Vancouver, Canada
}

\author{
Gunilla Öberg $^{1}, \underline{\text { Maria G. Merlinsky }}^{2}$, Alicia LaValle $^{1}, \underline{\text { Margaret Morales }}^{1}$ and Melina M. Tobias ${ }^{2}$
}

\begin{abstract}
The need for a radical shift to more iterative and adaptive solutions in sewage management is increasingly recognized, but our ability to achieve such a shift is constrained by inertia to change. Here, we describe planning in two metropolitan areas that are upgrading their sewage systems, based on interviews with central actors and official documents. Using new institutionalism and concentrating on changes in normative, regulative, and cognitive patterns, we analyze if obstacles to the uptake of innovations can be understood in light of how these patterns counteract institutional change. Our aim is to understand obstacles to reformers implementing a wider vision of sewage management. Our study suggests that even though both Buenos Aires and Vancouver emphasize the need for integrated water management, it does not seem likely that either will implement a solution that challenges the end-of-pipe paradigm. We conclude that the main obstacle to change is the deeply rooted cognitive notion that sewage is waste. Framed as waste, sewage becomes something a community needs to get rid of, the faster the better. The notion of sewage being a worthless burden means that it is expected to generate costs, not revenues. When sewage is foremost framed as waste, the conventional linear end-of-pipe solution becomes the most logical way to manage it. We argue that this notion permeates the entire institutional structure and that its power is not recognized. We speculate on whether a shift toward iterative and adaptive solutions might be facilitated if sewage were redefined outside the water management umbrella and instead understood as resource management (for example, energy and nutrients), and if organizations responsible for delivering sewage services were reorganized accordingly.
\end{abstract}

Key Words: inertia to change; sewage management; waste vs. resource; wastewater; water management

\section{INTRODUCTION}

More than one-half of today's global population lives in urbanized areas, and most predictions suggest that the urbanization trend will continue for the foreseeable future. One of the challenges following this trend is to provide growing urban populations with sewage services in an equitable manner. Expectations are becoming increasingly complex as social priorities change, for example, bringing stricter regulations for water source pollution (Allbee 2005, Cashman and Ashley 2008, Marlow et al. 2010). It is commonly argued that planning for sustainable development requires a radical shift from the prevailing linear approach to sewage management to a triplebottom-line perspective founded on iterative and adaptive solutions (Folke et al. 2005, Armitage et al. 2007, Pahl-Wostl 2009). Resource recovery plays a central role in the envisaged model of sustainable sewage management for its potential to create net-positive values via reduction, reuse, and recycling of water, energy, and nutrients (e.g., Brooks 2006, Burn et al. 2010). The assumption is that reducing losses and consumption and increasing efficiencies in reuse and recycling will reduce necessary resource input. This, in turn, is anticipated to reduce environmental impact, cost for energy and other resources, and render a net-positive socio-cultural impact (Koutsovitis 2012). In addition, reducing the pollution to receiving waters, which also serve as drinking-water sources, holds the potential to reduce future costs of increased purification needs, remediation of damaged ecosystems, and the need to develop other potable water sources. In light of these predicted outcomes, considerable attention has been given to innovative technologies, but uptake has been slow (Panebianco and Pahl-Wostl 2006, Lemos 2008, Brown and Farrelly 2009). From a sustainability perspective, the question begs an answer: What obstacles in our current sewage management paradigm prevent reformers from adopting and implementing a wider vision of sewage management, particularly when necessary system upgrades, expansions, and improvements offer an opportunity to use sewage beneficially as a resource?

\section{THEORETICAL FRAMEWORK}

Attempts have been made to understand barriers to change in sewage management based on the belief that a shift is required from "the traditional, linear, 'old-world' approach to an adaptive, participatory and integrated approach" (Brown and Farrelly 2009:839; see also Scott 1995, Healey 1997, Lemos 2008, Marlow et al. 2010). We agree with this normative approach. Inherent to most large-scale and complex socio-technical systems is a certain amount of inertia, or resistance to change (Lach et al. 2005, Panebianco and Pahl-Wostl 2006). It is commonly agreed that changes in planning and management in the sector are difficult to achieve because sewage, water, and energy are traditionally defined as separate entities (Brown et al. 2009, Marlow et al. 2011), and the institutions and ideals that guide and underlie large-scale system infrastructure and development are not easily changed (Nilsson 2006).

Several authors argue that to instigate change, we need to improve our understanding of how transitions from one system paradigm to another can be facilitated. Drawing a new institutionalism framework, a socio-technical system can be understood as resting on three reinforcing pillars that need to support change mutually if change is to take place:

1. Regulative: administration, rules, and systems. Rules and systems are designed to protect dominant values (normative) and thinking (cognitive). The growing focus on environmental protection and sustainability has seen the gradual introduction of legislation and regulation aimed at protecting natural water environments. 
2. Normative: values and leadership. An example of changes to values in the urban sewage sector is the growing focus on the importance of environmental protection and the remediation of waterways.

3. Cognitive: dominant knowledge, thinking, and skills. An example of changing cognition in the sewage sector is the growing dialog around water-sensitive urban design (WSUD), which conceptually challenges traditional notions of sewage management (adapted after Brown et al. 2009:848).

Our aim is to analyze how obstacles to sewage-related innovations can be understood in light of how these three pillars counteract institutional change. Based on this analysis, we ask what the obstacles are to reformers acting on opportunities to adopt a wider vision of sewage management.

\section{METHODS}

Our study is based on an analysis of data from Gran Buenos Aires, Argentina and Metro Vancouver, Canada. The cases are chosen as examples of coastal metropolitan areas with central sewage systems originating from the late 19 th century. Both areas are in the process of upgrading their aging and insufficient infrastructure. The historic, geographic, and demographic development patterns in the two chosen areas are similar in many aspects, and we assumed that these similarities would facilitate an analysis of how institutional factors may affect change in sewage management in growing coastal metropolitan areas.

Documents regarding liquid waste management guidelines and planned upgrades available on official websites were analyzed, and semi-structured interviews were conducted 2010-2011 with central actors in the planning process. Interviewees were identified via the snowball method; conversations lasted approximately $1 \mathrm{~h}$ in Vancouver and $2 \mathrm{~h}$ in Buenos Aires and were recorded and transcribed. The 17 interviews carried out in Buenos Aires were part of a larger project dealing with political challenges related to remediation of the Matanza-Riachuelo watershed and the creation of the watershed authority ACUMAR in 2005 (Merlinsky 2011a,b). After an introduction to the scope of the study, interviews in Buenos Aires commenced with questions related to the professional roles and responsibilities of the interviewees, followed by questions related to the implementation of ACUMAR's directive, with specific attention to the recently initiated expansion of the sewage infrastructure and integrated water management. The five interviews carried out in Vancouver were more limited in scope and focused on the 2009 update of Metro Vancouver's liquid waste management plan (LWMP) and the process leading up to the submission of the plan in May 2010, with specific attention on integrated resource recovery (Metro Vancouver 2010). A more detailed description of the interviews conducted in Vancouver is given by Morales and Öberg (2012).

The interviews were coded for themes that indicated changes in regulative, normative, and cognitive structures, which were analyzed in the light of information found on the websites and official documents, looking for convergences and differences in the storylines that emerged in each urban center. The following description of the historic development and geographic context of each metropolitan area is based on official documents.

\section{SEWAGE SERVICES: PAST AND PRESENT}

\section{Geographic context}

Argentina and Canada are spatially large countries with small populations relative to their size, with the majority of residents living in urban areas (Fig. 1). Both countries are federations with complex distribution of responsibilities between the federal government, provinces, metropolitan regions, and municipalities. The metropolitan areas of Vancouver and Buenos Aires are approximately of the same size, but the population of Buenos Aires is nearly six times larger than that of Vancouver (approximately 13 million vs. 2 million inhabitants, Fig. 1). Both areas are the result of European colonization, but Vancouver is comparatively young: The first permanent European settlements in Buenos Aires date back to 1580, whereas the first permanent European settlements in Vancouver date to 1862. Both areas have continued to be immigrant cities, with a continuing strong influx from Europe. At present, resource-poor immigrants from other Latin American countries dominate the influx to Buenos Aires, whereas resource-rich, overseas immigrants from the Asian continent dominate the influx to Vancouver.

Fig. 1. Geographical locations of the two case studies.

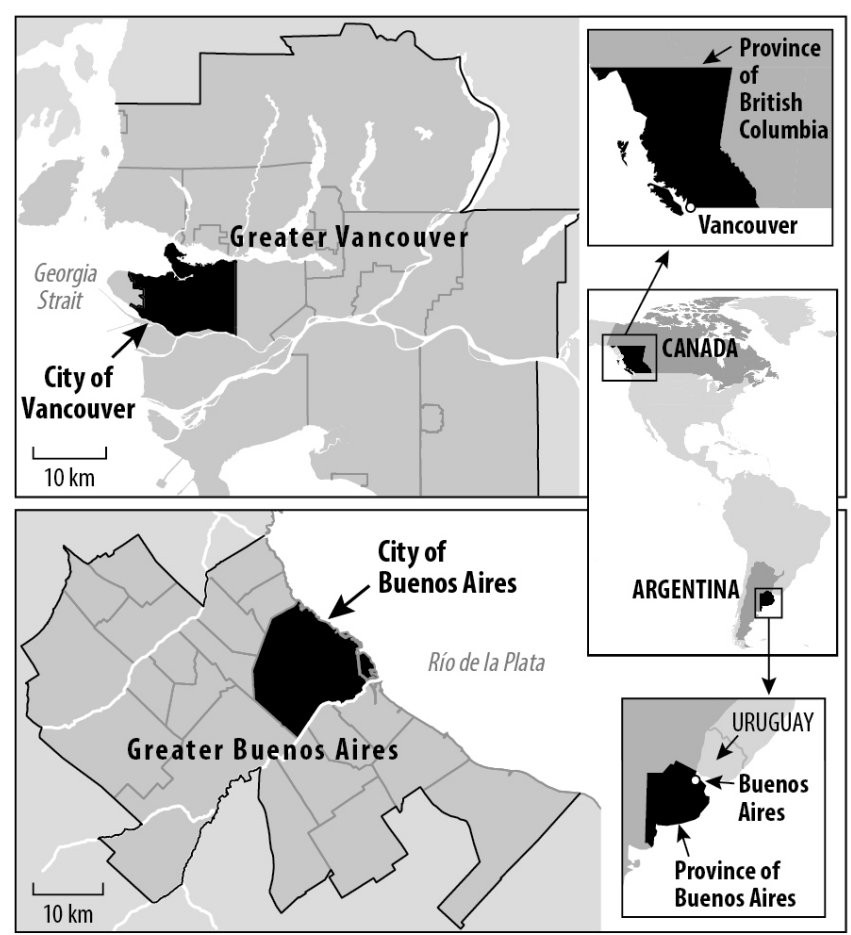

Gran Buenos Aires consists of the jurisdictionally autonomous City of Buenos Aires plus 24 municipalities (Atlas Ambiental de Buenos Aires 2010). The City of Buenos Aires is the largest city in Argentina, and the metropolitan area started to grow exponentially at the end of the 19th century (Instituto Nacional de Estadísticas y Censos 2001, 2010; Fig. 2). The City of Vancouver is one of the 22 municipalities that make up Metro Vancouver (Metro Vancouver, history: http://www.metrovancouver. 
org/about/Pages/history.aspx). Vancouver is the third largest city in Canada, and the population began to grow exponentially in the 1940s (Metro Vancouver 2011a; Fig. 2).

Fig. 2. Population growth over time in the City of Buenos Aires and Gran Buenos Aires (left) and the City of Vancouver and Metro Vancouver (right).

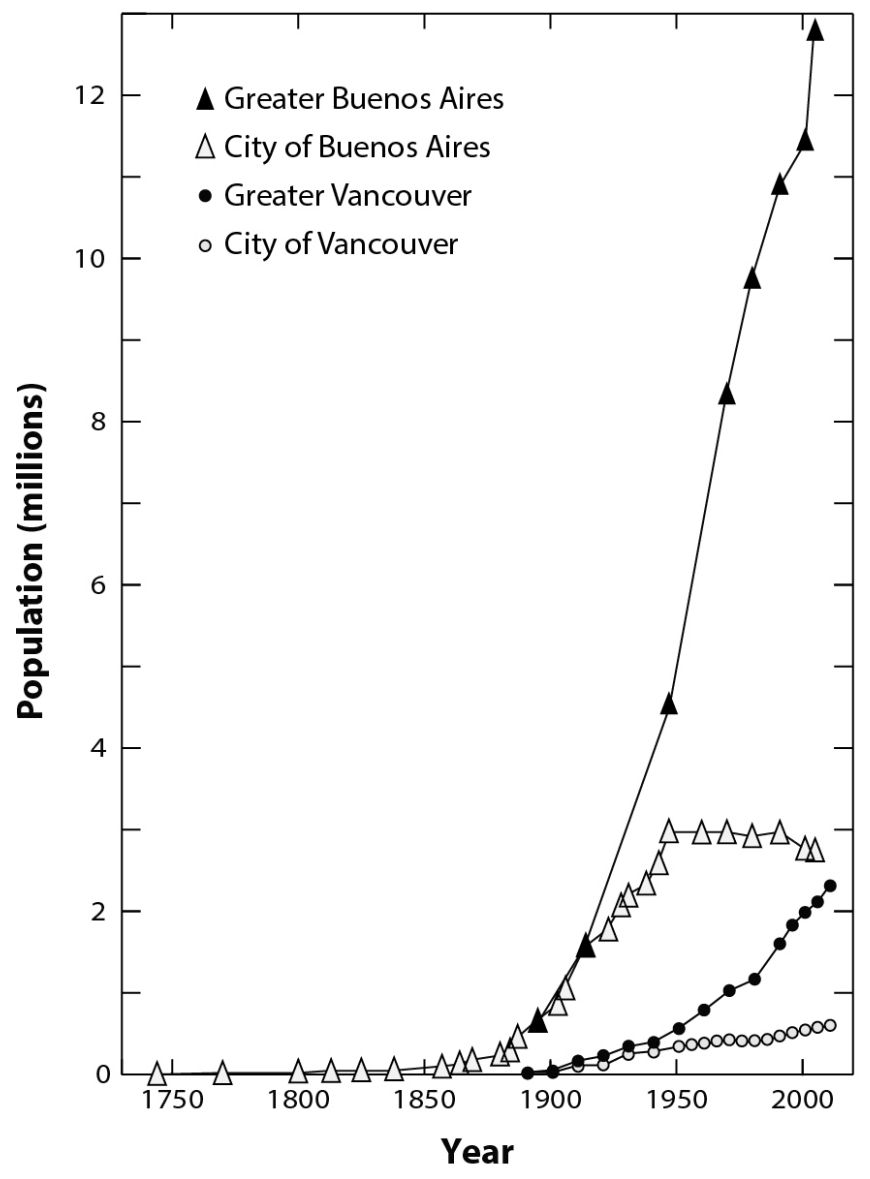

Sewer systems

The sewer systems in both locations date back to the second half of the 19th century, when the majority of urban centers in the western world built such systems (George 2008). Services in both places are presently provided by a centralized, publically owned, regional administration. In Argentina, these services were managed at the federal level from the middle of the 20th century. Declining service levels led to a series of reforms attempting to correct the situation. A failed privatization reform in the 1990s, initially hailed as a success (Alcázar et al. 2000, Water and Sanitation Program 2001), was followed by a counter-reform in 2006 and subsequent creation of AySA (Aguas y Sanaemientos), the federally owned enterprise that presently provides water and sewage services in Gran Buenos Aires (Casarin et al. 2007, Ordoqui Urcelay 2007, Cirelli and Ojeda 2008, Romero Lankao 2011). In 2005, a parallel reform led to the creation of the watershed authority ACUMAR and more stringent rules with regard to the effluent quality to the receiving water bodies in the
Matanza-Riaucheulo watershed, which covers the southern districts of the metropolitan area (Merlinsky 2013).

Sanitation development in Vancouver has been more linear. As the population began to grow in the early 20 th century, a number of smaller private and public water utilities were combined, forming the public entity known today as 'Metro'. This entity still carries the responsibility to provide sanitation services to the region (Metro Vancouver 2011b).

Residents in both metropolitan areas expect that the government will see to it that they will not need to concern themselves with sewage issues other than flushing the toilet. This expectation of sewage treatment as a right of an urban citizen is representative of a common cultural norm in most modern cities. This luxury, however, does not include inhabitants in the poorer neighborhoods of Gran Buenos Aires, where the public service provision is erratic (Morales et al. 2014): Only 59\% of the population is connected to central sewers. The sewage from the remaining $41 \%$ is handled on-site via septic tanks, pit latrines, or cesspools, leading to severe pollution of groundwater and local watercourses (AySA 2006). It should be noted that $90 \%$ of the population has access to running water, and also, that those not connected to the central sewer system have water-flushed toilets.

In Gran Buenos Aires, only $10 \%$ of the collected sewage is treated to primary level; the rest is discharged untreated in the local watercourses. In contrast, close to $100 \%$ of the collected sewage in Metro Vancouver is funneled to one of five sewage treatment plants. Two treat the sewage to an advanced primary level, and three treat the sewage to secondary level (Metro Vancouver 2010).

\section{PLANNING FOR THE FUTURE}

In Buenos Aires, a strategic plan was established in 2005 that outlines how $95 \%$ of the population will be connected to the central sewerage system by 2020 (AySA 2006, 2010). Several of our interviewees used terms such as "monstrous" when describing this undertaking, which consists of a number of interlinked largescale infrastructure development projects (Merlinsky 2013).

The strategic plan for the sewage system in Metro Vancouver was approved in 2011 and outlines visions, goals, and major challenges to achieving sustainable wastewater management (Metro Vancouver 2010). Our interviewees explained that the new federal legal requirement to treat sewage to secondary level is driving upgrades of two existing treatment plants. In contrast to earlier strategic plans, the 2011 document stresses the need for sustainable development and highlights integrated resource recovery.

Drawing on documents from the websites of both Metro and AySA, it seems safe to say that the traditional end-of-pipe solution has historically been the guiding principle for planning and implementation in both locations. Next, we analyze our data in light of the question: Does it appear as if normative, regulative, and cognitive shifts are underway in each location that support or counteract a shift to more iterative and adaptive solutions?

\section{Buenos Aires}

Regulatory shift

Several interviewees expressed that they saw the 1990s privatization reform as an improvement to the sewage management system in that it led to a less bureaucratic and more 
efficient organization, but that the lack of regulation and control opened opportunities for exploitation and increased inequalities. It was commonly held that the increasingly inequitable service levels and the lack of compliance and control were major drivers behind the regulative overhaul of 2006. A parallel reform leading to the creation of the watershed authority ACUMAR (Merlinsky 2013) was also mentioned as a driver, not least the more stringent rules for effluent quality to the extremely polluted MatanzaRiachuelo River.

\section{Normative shift}

Almost all of the interviewees emphasized that water and sanitation play a key role in poverty eradication: "He who does not have water or good sanitation services does not live well" (Interviewee 14). References to the Millenium Goals were prevalent in the interviews, and "access to water is a human right" was a commonly repeated line. This suggests that a normative shift preceded the regulatory shift: Water must be provided equitably, and because privatization led to increased inequalities, it had to be reversed. Some of the interviewees felt that the reversal of the privatization of sanitation service provision was inevitable, as "the market doesn't care about the poor" (Interviewee 5).

Some interviewees argued, however, that the reason for system decay and service inequalities is less a question of private vs. public, and more a question of a lack of clear rules, inconsistent control, and bad management: "There are bad private enterprises and good private enterprises, just as there are good and bad public ones" (Interviewee 14). Alcázar et al. (2000) claim that the first reform was driven by the argument that the market would be able to reverse the deterioration of the system that was already extensive. Even though it is tempting to interpret the prevalent "equity speak" in some of our interviews as a sign of a normative shift preceding the regulatory shift, our material does not allow us to say whether or not this is more than a question of ideologically based rhetoric or if it can be taken as an indicator of an actual normative change.

Another potential sign of a normative shift was the commonly raised ecological concerns. These were mainly made in reference to the extremely polluted Matanza-Riachuelo River, which is the recipient of untreated sewage from several million people (Merlinsky 2011a). The oft-repeated references to ecological concerns in the strategic plan itself, in documents discussing the plan, and by our interviewees, could indicate a shift toward a more biocentric perspective, given that we could not find any references to any such concerns in documents prior to the 2006 plan. One of the experts we spoke with explained that a hydro-chemical model showed that the plan would result in a dramatically improved ecological situation, and he claimed that this was why the World Bank approved a major loan to support the infrastructure upgrades (Interviewee 16). It is noteworthy that the references to the Millennium Goals and remediation of local watercourses were mainly made in relation to funding. Upon reviewing the interviews, there was a sense that the ecology-based arguments were more rhetoric adjustments in relation to demands made by funders, rather than evidence of a pervasive normative shift, for example, based on a belief that nature should be protected because it has intrinsic value.

\section{Cognitive shift}

Our interviews suggest a major cognitive shift from seeing the piped water system as separate from the natural water system, to a perspective where they are integrated in a watershed. We base this conclusion on three observations. First, every interviewee gave us tutorials on watershed hydrology in a way that suggested that these concepts were fairly new to them and/or they assumed that these concepts were new to us. Second, we could not find any signs of watershed-based conceptualization of the urban watercycle in official documents pre-dating ACUMAR's creation, whereas such references are commonly occurring in post-dated ones. Finally, our conversations on integrated water management were dominated by comments related to watershed-based management, with the imbalance between water and sewer provisioning as the most pressing problem because it led to an imbalance in the water cycle. Interviewees' descriptions of the hydrological system inferred that it is crucial to rid the area of the excess water as quickly as possible. Under this framing, the logical conclusion is larger pipes. It thus seems as if the cognitive shift to an integrated watershed perspective reinforces, rather than challenges, the conventional end-of-pipe approach.

\section{Vancouver}

\section{Regulatory shift}

As mentioned above, a new federal law is under implementation in Canada, with higher effluent quality standards. This will require changes in Metro Vancouver's two older treatment plants. All five interviewees mentioned this as a driver of change and a window of opportunity for implementation of solutions geared toward integrated resource recovery.

\section{Normative shift}

The new sewage plan distinguishes itself from the previous plan in that long-term sustainability is spelled out as a clearly formulated goal and integrated resource recovery is forwarded as a desirable outcome. Our interviewees emphasized that this language mirrors a general trend in Vancouver's policy documents, which are all colored by the region's sustainability initiative, SRI. The introduction of sustainability as an overarching goal in liquid waste management, which is consistently mirrored in all recent policy documents, seems to indicate that a normative shift is underway in the organization, in support of a strategic and systematic implementation of more sustainable solutions. Similar to the case of Buenos Aires, there is some evidence that this language of sustainability has emerged first as a rhetorical move, perhaps in response to cultural expectations in Vancouver of being at the forefront of the "green" movement, and that it may be slow to manifest concretely in decision-making. Two of our interviewees (Interviewees 22 and 23) expressed skepticism that Metro was ready to adopt any major changes in sewage management systems based on stated sustainability criteria.

\section{Cognitive shift}

Our interviews suggest that there is a cognitive shift underway in that the interviewees believe that those in charge of the upgrade process are becoming supportive of resource recovery, even if only in theory. Our interviewees from Metro stressed that the staff has direct access to leading experts via advisory committees, and that they are working to implement the best possible solution given 
all factors (Interviewees 19, 20, and 21). One interviewee from the advisory committee (Interviewee 23 ) discussed the committee's considerable difficulties in getting their suggestions actually incorporated into the final LWMP. The consultant (Interviewee 22) also felt that the support for resource recovery was more in word than in action. As we discuss next, this cognitive shift toward resource recovery has yet to affect financing paradigms for major utility projects so that future revenue generation is accounted for in the project financing schemes (this is also further discussed by Morales and Öberg 2012). Two of the interviewees were less optimistic than the others, as they felt that the support for resource recovery was more in word than in action.

\section{WHAT ARE THE OBSTACLES TO CHANGE?}

Our study thus suggests that even though both Buenos Aires and Vancouver emphasize the need for integrated water management, it remains unlikely that either will implement a solution that challenges the end-of-pipe paradigm.

The response to Buenos Aires' existing sewage system failures is more, larger, and longer pipes. This represents only a slightly modified version of the end-of-pipe solution developed in 1940 (Interviewee 5). In light of our admittedly light-brushed institutional analysis, this is the expected response, as none of the regulative, normative, or cognitive shifts at work would support change toward more adaptive sewage management solutions. On the contrary, these shifts appear to be reinforcing existing end-ofpipe thinking. In Vancouver, our initial analysis indicated that one would expect change to happen: the new federal law provides regulatory support, the emphasis on sustainability in the regional vision provides normative support, and cognitive support is provided from Metro staff embracing the idea of resource recovery, supported by access to experts in innovative fields. Still, our interviews suggest that a shift from the linear end-of-pipe model remains unlikely. Our conclusion is that this is because of a deeply rooted notion that sewage first and foremost is waste. Under this cognitive framing, the logical response is to simply retrofit the existing system: fix leaky pipes, rid the system of combined sewers, and recover more biogas at the end of the pipes. This is also only a slightly modified version of the 19th century end-of-pipe solution.

Does this analysis help us understand why reformers in each context are not bringing about change toward more iterative and adaptive sanitation solutions?

\section{The notion of sewage as waste (and not a resource)}

Our major conclusion is that the main reason why reformers do not see these necessary infrastructure changes as opportunities to introduce more adaptive sewage management solutions is what Lemos (2008) refers to as a "perception of knowledge fit" or what Fleck (1979) calls "thought styles". The former argues that the degree to which a proposed solution fits with managers' perception of the problem determines their willingness to accept it. Fleck (1979) argues that the way an individual thinks and speaks about something determines the kinds of solutions they are able and willing to contemplate. Our study suggests that this framing is not limited to various individuals' ways of thinking, but is deeply embedded in the three institutional pillars and mirrored in legal and strategic documents.

Our impression from both locations is that the widely embraced notion that sewage is first and foremost waste is a major cause of the locked-in effect to end-of-pipe solutions in sewage management. Framed as waste, sewage is something a community needs to get rid off, the faster the better. Speed is central to efficient handling of sewage in this paradigm, as cost is directly related to how much this burden is handled. End-of-pipe water-borne sewage management models prioritize speed and this makes them the most logical solution when sewage is defined as waste.

We were told that an advisory group in Vancouver had fought hard to replace the word "waste" with "resource", as this would help to change the thinking around sewage. This effort was partially successful, for example, in getting the word "resource" into a key document's title (Interviewee 5, Vancouver). Still, the way the title is phrased makes it quite clear that resource is a subordinated term and that sewage is still first and foremost seen as waste: Integrated Liquid Waste and Resource Management: A Liquid Waste Management Plan for the Greater Vancouver Sewerage \& Drainage District and Member Municipalities. In Buenos Aires, there was considerably less mention of sewage as a resource in interviews as well as documents. When framed as waste (with resource as an afterthought, if at all), there is little reason for major change.

\section{Waste generates costs (not revenues)}

The fact that sewage is first and foremost is framed as waste in both locations was most clearly expressed in discussions related to the financial challenges of sewage management; these provided ample evidence that the notion of sewage as a resource is far from embraced. Our interviews suggest that neither location is anticipating or even recognizing the possibility of revenue generation from liquid waste. The chief engineer in Buenos Aires immediately dismissed the idea that one might decrease costs via reuse, recycling, and revenues created by resource recovery (water, energy, nutrients) as utopian (Interviewee 5). It was not a question of being unfamiliar with these solutions: the AySA staff we interviewed were very aware of the technical developments related to water reuse, energy recovery in Europe and the United States, and saw countries such as Chile and Brazil as being at the forefront of these developments in Latin America. However, resource recovery was perceived as perhaps suitable for wealthier nations. The idea that active sewage management might reduce future costs by decreasing pollution of receiving waters that also serve as a drinking water source was literally laughed at. In line with this thinking, the introduction of inverse osmosis in a recently built water purification facility was touted as an innovative solution, rather than as an expensive remediation forced by the increasingly poor water quality caused by inadequate sewage treatment.

Two interviewees in Vancouver expressed frustration at the extreme difficulties in getting Metro to abandon the idea that sewage service must rely on a cost-based model. They argued that it makes sense to accept a higher initial investment cost in resource recovery solutions as such solutions open opportunities for revenue generation in the long run, which will not only cover the initial investments but also reduce maintenance and operational costs. A shift from the existing cost-based model to a revenue generation model requires that sewage first and foremost be seen as a resource with inherent value that can be harvested, rather than a burden that only carries costs.

Sewage as waste is embedded in the entire institutional structure When speaking about infrastructure, it is commonly argued that alternative models are particularly difficult to introduce in this 
field because sewage infrastructure is long-lived and literally sunk into the ground (Gleick 2003, Nilsson 2006, Panebianco and PahlWostl 2006, Brown et al. 2009, Larsen et al. 2009, Burn et al. 2010). This may be true for places like Vancouver, where retrofitting old infrastructure is a major challenge. In contrast, in unevenly developed urban areas like Buenos Aires, the lion's share of the sewage upgrade entails constructing new infrastructure. Still, the inertia to change remains strong, even thought they are not locked into existing infrastructure. What both locations do share are rigid regulative, normative, and cognitive structures organized around the notion that sewage is waste and that water-borne sewer lines offer the fastest and most affordable means of getting rid of it.

It appears that the notion of sewage as waste is embedded in the entire institutional structure. The power of this notion is, however, not recognized and forms a monumental obstacle to reformers in implementing a wider vision of sewage management.

\section{Might change be coming?}

Though somewhat counterintuitive, the current resistance to adopting more adaptive sewage management solutions may lead to crisis in both locations that eventually force change. Kuhn (1962) describes this as the kind of crisis needed for paradigmatic shift.

The haphazard urban growth pattern in Buenos Aires, in combination with a significant lag in connecting many neighborhoods to existing infrastructure, could potentially lead to an urban planning crisis and awaken Buenos Aires to cognitive shifts that support alternative solutions. Flexibility is one of the major arguments for decentralized solutions (Guest et al. 2010). Because it is generally assumed that Buenos Aires will continue to grow in a haphazard manner, despite planning efforts, the inflexibility of the proposed expansion of the centralized system in Buenos Aires makes it particularly unsuited to this location. Several of our interviewees in fact argued that the city's haphazard "organic" growth is the very reason why the centralized "monster project" will never succeed in providing services for all, even if implemented. Interviews with nongovernmental organizations and community organization representatives suggest that organizations in some of the underserved areas are seeking solutions and gathering arguments to convince authorities to implement decentralized solutions. This demographic crisis, which has not only prevailed but worsened in spite of the various reforms, might induce a refocusing in the problem perception because it challenges the present centralized "larger-and-longerpipes" solution. Decentralized systems are undeniably more flexible than central ones; however, they do not automatically challenge the linear end-of-pipe paradigm (they may simply rely on smaller and shorter pipes). It remains to be seen if the indicated leadership approach, from the bottom up, will embrace regenerative solutions based on the notion of sewage as a resource, for example, spurred by the looming energy crisis in the country, which could raise the interest and awareness of potential benefits of resource recovery.

The Vancouver case is different because the region does not have large areas that lack sewer infrastructure. Still, increasing costs in this context may be seen as a creeping crisis that eventually pushes a shift in support of viewing sewage as a resource that the city cannot afford to waste. Our conclusion is that change in this context requires a deep cognitive shift among reformers and planners to recognize that the notion of sewage as waste is an obstacle to change, and one that is deeply embedded in their organizational structure. Studies in change management argue that change requires that a strategic plan be put in place to translate vision into implementation; if this is not done, ingrained structures will prevail (Frantzeskaki et al. 2012).

In both study areas, sewage was clearly understood as a subsection of the broader water management paradigm. This is not surprising, as this is how sewage is normally framed nowadays, from organizational, administrative, regulatory, technical, and academic points of view. In the English language, we normally speak of sewage as wastewater, thus defining it as useless. We raise the question whether this framing of sewage as a sub-section of water management further reinforces linear, end-of-pipe solutions. A shift toward more iterative and adaptive solutions might be facilitated if sewage were redefined outside the water management umbrella and understood as resource management (for example, energy and nutrients), with organizations responsible for delivering sewage services organized accordingly.

Responses to this article can be read online at: http://www.ecologyandsociety.org/issues/responses. $\mathrm{php} / 6531$

\section{Acknowledgments:}

This study was made possible through financial support from the Martha Piper Foundation and CONICET.

\section{LITERATURE CITED}

Aguas y Sanaemientos (AySA). 2006. Plan de saneamiento 2006 2020: acceso universal a los servicios para milliones de argentinos. AySA, Buenos Aires, Argentina. [online] URL: http://www.aysa. com.ar/Media/archivos/393/Folleto puntual Plan de Saneamiento_de_AySA_2007-2020.pdf.

Aguas y Sanaemientos (AySA). 2010. Informe al usuario. Datos a diciembre de 2009. Expansión y desarrollo: trabajamos para el desarrollo y bienestar de la comunidad. AySA, Buenos Aires, Argentina. [online] URL: http://www.aysa.com.ar/Media/ archivos/391/Informe al Usuario 2009.pdf.

Alcázar, L., M. A. Abdala, and M. M. Shirley. 2000. The Buenos Aires water concesion. World Bank Policy Research Working Paper 2311. [online] URL: http://papers.ssrn.com/sol3/papers. cfm?abstract id $=630683$.

Allbee, S. 2005. America's pathway to sustainable water and wastewater systems. Water Asset Management International 1 (1):9-14.

Armitage, D., F. Berkes, and N. Doubleday, editors. 2007. Adaptive co-management: collaboration, learning, and multi-level governance. UBC Press, Vancouver, Canada.

Atlas Ambiental de Buenos Aires 2010. Infraestructura de los servicios de cloacas. Grupo de Investigaciones Geoambientales, 
Buenos Aires, Argentina. [online] URL: http://www. atlasdebuenosaires.gov.ar/aaba/index.php?Itemid=154\&id=314\&option= $\underline{\text { com content \&task }=\text { view\&lang }=\text { es }}$.

Brooks, D. B. 2006. An operational definition of water demand management. International Journal of Water Resources Development 22(4):521-528. http://dx.doi.org/10.1080/07900620600779699

Brown, R. R., and M. A. Farrelly. 2009. Delivering sustainable urban water management: a review of the hurdles we face. Water Science and Technology 59(5):839-846. http://dx.doi.org/10.2166/ wst. 2009.028

Brown, R. R., N. Keath, and T. H. F. Wong. 2009. Urban water management in cities: historical, current and future regimes. Water Science and Technology 59(5):847-855. http://dx.doi. org/10.2166/wst.2009.029

Burn, S., D. Marlow, and D. Tran. 2010. Modelling asset lifetimes and their role in asset management. Journal of Water Supply: Research and Technology-Aqua 59(6-7):362-377. http://dx.doi. org/10.2166/aqua.2010.001

Casarin, A. A., J. A. Delfino, and M. E. Delfino. 2007. Failures in water reform: lessons from the Buenos Aires's concession. Utilities Policy 15(4):234-247. http://dx.doi.org/10.1016/j. jup.2007.02.004

Cashman, A., and R. Ashley. 2008. Costing the long-term demand for water sector infrastructure. Foresight 10(3):9-26. http://dx.doi. org/10.1108/14636680810883099

Cirelli, A. F., and C. Ojeda. 2008. Wastewater management in Greater Buenos Aires, Argentina. Desalination 218(1-3):52-61. http://dx.doi.org/10.1016/j.desal.2006.10.040

Fleck, L. 1979. Genesis and development of a scientific fact. T. J. Trenn and R. K. Merton, editors. University of Chicago Press, Chicaco, Illinois, USA.

Folke, C., T. Hahn, P. Olsson, and J. Norberg. 2005. Adaptive governance of social-ecological systems. Annual Review of Environment and Resources 30:441-473. http://dx.doi.org/10.1146/ annurev.energy.30.050504.144511

Frantzeskaki, N., D. Loorbach, and J. Meadowcroft. 2012. Governing societal transitions to sustainability. International Journal of Sustainable Development 15(1-2):19-36. http://dx.doi. org/10.1504/IJSD.2012.044032

George, R. 2008. The big necessity: the unmentionable world of human waste and why it matters. Metropolitan Books, New York, New York, USA.

Gleick, P. H. 2003. Global freshwater resources: soft-path solutions for the 21 st century. Science 302:1524-1528. http://dx. doi.org/10.1126/science.1089967

Guest, J. S., S. J. Skerlos, G. T. Daigger, J. R. E. Corbett, and N. G. Love. 2010. The use of qualitative system dynamics to identify sustainability characteristics of decentralized wastewater management alternatives. Water Science and Technology 61 (6):1637-1644. http://dx.doi.org/10.2166/wst.2010.880

Healey, P. 1997. Collaborative planning: shaping places in fragmented societies. McMillan, London, UK.
Instituto Nacional de Estadísticas Censos. 2001. Censo nacional de población, hogares y vivienda 2001. Instituto Nacional de Estadísticas Censos, Buenos Aires, Argentina. [online] URL: http://www.indec.mecon.gov.ar/webcenso/.

Instituto Nacional de Estadísticas Censos. 2010. Censo nacional de población, hogares y vivienda 2010. Instituto Nacional de Estadísticas Censos, Buenos Aires, Argentina. [online] URL: http://www.censo2010.indec.gov.ar.

Koutsovitis, M. E. 2012. Pautas para el diseño sustentable de redes de distribución de agua potable. Encuentro de Investigadores del Agua Ezeiza, Instituto Nacional del Agua, Ezeiza, Argentina. [online] URL: http://www.ina.gov.ar/pdf/ifrrhh/01 029 Koutsovitis. pdf.

Kuhn, T. 1962. The structure of scientific revolutions. University of Chicago Press. Chicago, Illinois, USA.

Lach, D., H. Ingram, and S. Rayner. 2005. Maintaining the status quo: how institutional norms and practices create conservative water organizations. Texas Law Review 83:2027-2053.

Larsen, T. A., A. C. Alder, R. I. L. Eggen, M. Maurer, and J. Lienert. 2009. Source separation: Will we see a paradigm shift in wastewater handling? Environmental Science and Technology 43 (16):6121-6125. http://dx.doi.org/10.1021/es803001r

Lemos, M. C. 2008. What influences innovation adoption by water managers? Climate information use in Brazil and the United States. Journal of the American Water Resources Association 44 (6):1388-1396. http://dx.doi.org/10.1111/j.1752-1688.2008.00231. $\underline{x}$

Marlow, D. R., D. J. Beale, and S. Burn. 2010. A pathway to a more sustainable water sector: sustainability-based asset management. Water Science and Technology 61(5):1245-1255. http://dx.doi.org/10.2166/wst.2010.043

Marlow, D., L. Pearson, D. H. MacDonald, S. Whitten, and S. Burn. 2011. A framework for considering externalities in urban water asset management. Water Science and Technology 64 (11):2199-2206. http://dx.doi.org/10.2166/wst.2011.789

Merlinsky, M. G. 2011a. El plan integral de saneamiento ambiental de la Cuenca Matanza-Riachuelo: desafíos políticos para la gestión integrada de los recursos hídricos en la Región Metropolitana de Buenos Aires. Pages 259-322 in F. Isuani, editor. Politica pública y gestión del agua: aportes para un debatenecesario. Prometeo, Buenos Aires, Argentina.

Merlinsky, M. G. 2011b. Sustentabilidad urbana: escalas y actores. Revista Ciudades 91:14-21.

Merlinsky, M. G. 2013. Política, derechos y justicia ambiental: el conflicto del Riachuelo. Fondo de Cultura Económica, Buenos Aires, Argentina.

Metro Vancouver. 2010. Integrated liquid waste and resource management. A liquid waste management plan for the Greater Vancouver sewerage \& drainage district and member municipalities. City of Vancouver, Vancouver, Canada. [online] URL: http:// www.metrovancouver.org/about/publications/Publications/ IntegratedLiquidWasteResourceManagementPlan.pdf. 
Metro Vancouver. 2011a. Metro Vancouver 2040 backgrounder: Metro 2040 residential growth projections. City of Vancouver, Vancouver, Canada. [online] URL: http://www.metrovancouver. org/planning/development//strategy/RGSBackgroundersNew/ RGSMetro2040ResidentialGrowth.pdf.

Metro Vancouver. 2011b. Waterworks overview: history of the water system. City of Vancouver, Vancouver, Canada. [online] URL: http://www.metrovancouver.org/about/Pages/history.aspx.

Morales, M., L. Harris, and G. Öberg. 2014. Citizenshit: the right to flush and the urban sanitation imagery. Environment and Planning $A$, in press.

Morales, M., and G. Öberg. 2012. The idea of sewage as a resource: an introductory study of knowledge and decision making in liquid waste management in Metro Vancouver, BC, Canada. UBC PoWG Report. Institute for Resources, Environment and Sustainability, Vancouver, Canada. [online] URL: http://www.watergovernance. ca/wp-content/uploads/2012/03/Gunilla-Oberg-Sewage-as-aresource-13March2012.pdf.

Nilsson, D. 2006. A heritage of unsustainability? Reviewing the origin of the large-scale water and sanitation system in Kampala, Uganda. Environment and Urbanization 18(2):369-385. http://dx. doi.org/10.1177/0956247806069618

Ordoqui Urcelay, M. B. 2007. Servicios de agua potable y alcantarillado en la ciudad de Buenos Aires, Argentina: factores determinantes de la sustantabilidad y el desempeño. UN Economic Commission for Latin America and the Caribbean, Santiago de Chile, Chile. [online] URL: http://www.eclac.org/cgi-bin/getProd. asp?:xml=/publicaciones/xml/7/28847/P28847.xml\&xsl=/drni/tpl/ p9f.xsl\&base=/drni/tpl/top-bottom.xsl.

Pahl-Wostl, C. 2009. A conceptual framework for analysing adaptive capacity and multi-level learning processes in resource governance regimes. Global Environmental Change 19(3):354-365. http://dx.doi.org/10.1016/j.gloenvcha.2009.06.001

Panebianco, S., and C. Pahl-Wostl. 2006 Modelling sociotechnical transformations in wastewater treatment - a methodological proposal. Technovation 26(9):1090-1100. http://dx.doi.org/10.1016/ j.technovation.2005.09.017

Romero Lankao, P. 2011. Missing the multiple dimensions of water? Neoliberal modernization in Mexico City and Buenos Aires. Policy and Society 30(4):267-283. http://dx.doi. org/10.1016/j.polsoc.2011.10.007

Scott, R. W. 1995. Institutions and organisations. Sage, Thousand Oaks, California, USA.

Water and Sanitation Program. 2001. The Buenos Aires concession: the private sector serving the poor. Water and Sanitation Program, Buenos Aires, Argentina. [online] URL: https://www.wsp.org/sites/wsp.org/files/publications/sa_buenos.pdf. 